\title{
PROCEEDINGS OF THE SIXTEENTH INTERNATIONAL MACHINE TOOL DESIGN AND RESEARCH CONFERENCE
}


PROCEEDINGS OF THE

\title{
SIXTEENTH INTERNATIONAL \\ MACHINE TOOL DESIGN AND RESEARCH CONFERENCE
}

\author{
held in Manchester \\ 10-12 September 1975 \\ Edited by \\ F. KOENIGSBERGER \\ Professor of Machine Tool Engineering \\ University of Manchester Institute of Science and Technology \\ and \\ S. A. TOBIAS \\ Chance Professor and Head of Department \\ Department of Mechanical Engineering \\ University of Birmingham
}

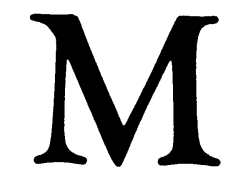


(c) The Macmillan Press Limited 1976

Softcover reprint of the hardcover 1st edition 1976 978-0-333-15058-0

All rights reserved. No part of this

publication may be reproduced or transmitted,

in any form or by any means, without permission.

First published 1976 by

THE MACMILLAN PRESS LTD

London and Basingstoke

Associated companies in New York Dublin

Melbourne Johannesburg and Madras

ISBN 978-1-349-81546-3

ISBN 978-1-349-81544-9 (eBook)

DOI 10.1007/978-1-349-81544-9

Published in the U.S.A.

by Halsted Press, a Division

of John Wiley \& Sons, Inc.

New York

Library of Congress Catalog Card No: 76-5219 


\section{OPENING SESSION}

Opening Address. H. O. BARRETT

\section{MANUFACTURING SYSTEMS}

The role of design in the introduction of a new machine tool. B. J. DAVIES

Long-range trends in the automation of machine tools and manufacturing. M. EUGENE MERCHANT

Today's DNC in Japan. SEIUEMON INABA and HAJIMU INABA

Processing of workpiece information for producing engineering drawings. G. SPUR and J. GAUSEMEIER

DNC systems in the electrical industry-examples of applications at Siemens AG. B. GUTT and E. JUNGMANN

Analysis of a direct numerical control system by means of real-time process simulation. M. WECK and A. SCHÜRING

The contribution of quality assurance to efficient production. L. SMITH

The optimum sequence of operations in the multistage manufacturing system. TATESHI KISHINAMI and KATSUMASA SAITO

Computerised archives and library system designed especially for manufacturing data. E. J. FEICHT

The use of a computer in a manufacturing system. M. Y. MALIK

Aspects of the control of manufacture in a small diecasting company. G. BEAUMONT and R. H. THORNLEY

Design and automatic set-up of drawings and work plans. W. EVERSHEIM and W. WIEWELHOVE

The design and implementation of an integrated computer production control system in a medium-sized engineering company. J. MALCOLM

The design of standard cells for group technology by the use of machine tool and workpiece statistics. MANSOOR HUSAIN and R. LEONARD

Layout design and simulation of group cells. ALLAN S. CARRIE and J. MANNION

\section{NUMERICAL CONTROL}

Improvement of adaptive control of milling machine by non-contact cutting force detector. KOJI NAKAZAWA

Adaptive control system for variable gain in ACC systems. G. STUTE and F. R. GOETZ

New automatic control system of NC machine tool for high working accuracy. M. MASUKO, N. NISHIWAKI, Y. KEMBO and B. S. SHIN

Profile accuracy of difficult-to-cut materials in computer numerical control. HIROSHI EDA and KOZO KISHI

A television-controlled printed circuit board drilling machine. D. PATERSON, A. R. TURNER-SMITH, J. A. G. HALÉ and P. SARAGA

NC-CNC, what prospects has CNC to offer? R. BAISCH 


\section{MACHINE TOOL DESIGN}

Computing the thermal behaviour of machine tools using the finite element method-possibilities and limitations. M. WECK and L. ZANGS

An analysis of methods used in minimising thermal deformations of machine tools. KEIJI OKUSHIMA and YOSHIAKI KAKINO

Control of the thermal deformation of a machine tool. T. SATA, Y. TAKEUCHI and N. OKUBO

Analysis and optimisation of structural dynamics of machine tools by a synthesis of dynamic rigidity program system. MASATAKA YOSHIMURA

Automatic optimisation of dynamic dampers for machine tool structures. H. VAN BRUSSEL, J. PINTE and K. SOUDAN

Damping in taper roller bearings. M. ELSERMANS, M. HONGERLOOT and R. SNOEYS

New developments in program control applied to big turret lathes. IAN NICKOLS

Presentation of a programmable controller with bit and word processing. G. STUTE and H. JETTER

Pneumatic stepping motors-design, control and application. H. K. TOENSHOFF and K. RALL

Computer-aided design and manufacture of rolls for cold roll forming machines. A. RHODES, T. MUNRO and A. S. BOARDMAN

Large rototraversing doughnut-type table for the machining of nuclear vessels. G. ZUFFELLATO

Design procedure for flat aerostatic bearings. J. C. PADATE and S. SOMASUNDARAM

\section{SPECIAL PROCESSES}

Some effects of electrolyte flow rates on the electrochemical machining process. P. J. MOIR and S. J. HARVEY

Electrochemical machining of curved long flowpath profiles. P. J. MOIR and S.J. HARVEY

Planetary spark erosion-application and optimisation. G. N. LEVY and B. FERRONI

Friction welding. G. R. DICKSON and A. S. BAHRANI

Slide pressure welding. N. BAY, P. M. KVIST and F. RASMUSSEN

Reclamation processes of machining swarf by consolidation and their economic feasibility. C. S. SHARMA and T. NAKAGAWA

\section{MACHINE TOOL OPERATION}

A statistical approach to machine tool testing. A. GOLDER

The reliability and value of tests to determine the limitations of the performance of lathes imposed by self-excited vibration. H. BEESON and A. GOLDER

An investigation of the use of cutting tests to assess the performance of lathes. $C$. CONST ANTINESCU, N. D. CIRTU, G. PAXINO, H. BEESON and A. GOLDER

A survey of the noise levels of metal-cutting machine tools. N. D. CIRTU, R. DIMITRIU, D. HARTLEY and A. GOLDER

Determination of a performance value for machine tools with respect to noise emission and proposals to its improvement by design. H. K. TOENSHOFF and G. ROHR

A study on the dynamic machining of free machining steel. R. RAMASWAMI, H. VAN BRUSSEL and P. VANHERCK

\section{GRINDING}

The proper selection of grinding conditions in cylindrical plunge grinding. J. PETERS, R. SNOEYS and A. DECNEUT

Grindability of tool steels from the viewpoint of surface quality. IVO KVASNICKA

The identification of grinding faults from the appearance of the ground surface. $\mathrm{H}$. RENKER

Improved technical and physical utilisation of vertical surface grinding machines by peripheral face grinding. R. REINHOLD 
The mechanics of swing forging. J. M. ALEXANDER and M. A. CHAABAN

A study on plastic working of alloys in their mashy state-the second report. S. FUKUOKA, M. KIUCHI and K. ARAI

A new method of manufacturing wire. M. C. SHAW and T. HOSHI

Incremental forging of balls from cylindrical specimens and of rollers from rectangular solids. N. R. CHITKARA, W. JOHNSON and M. UEDA

Lubrication for warm forming. T. A. DEAN

The effect of seal position on stresses and deformations in dies for semi-continuous hydrostatic extrusion. J. M. ALEXANDER and M. E. SAID

A method of obtaining isothermal, constant high strain rate stress-strain data. $M$. MOHITPOUR and B. LENGYEL

Deep-drawing of tin-plate using a telescopic punch. S. R. GURUMUKHI and P.B. MELLOR

An investigation into the hole-flanging of $\mathrm{Zn}-\mathrm{Al}$ superplastic sheet. G. G.W. CLEMAS, S. T. S. AL-HASSANI and W. JOHNSON

Deep-drawing of square shells with rubber die. K. YAMAGUCHI, M. FUKUDA and M. YOKOTA

Observations on the application of limit diagrams to aluminium alloy extrusion. $\mathrm{T}$. SHEPPARD and A. F. CASTLE

\section{METAL CUTTING}

Resistance of alumina tool tips to formation of comb cracks. R. M. El-ZAHRY and D. S. DUGDALE

Some experiments to compare diamond and diamond-compact turning tools. M. CASEY and J. WILKS

Deformation of tungsten carbide tools when cutting Inconel 718. A. E. FOCKE, F. E. WESTERMANN, A. ERMI, J. YAVELAK and M. HOCH

Continuous measuring of flank wear. TH. STÖFERLE and B. BELLMANN

Economic generation of tool life data using the $R-T$ characteristic curve. M.Y. FRIEDMAN, V. A. TIPNIS and M. FIELD 